OPEN ACCESS

Edited by:

Manuel Delgado Baquerizo, University of Alicante, Spain

Reviewed by:

Haiyan Chu,

University of Chinese Academy

of Sciences, China

Gavin Lear,

The University of Auckland,

New Zealand

*Correspondence:

Kyle M. Meyer

kmmeyer@berkeley.edu

${ }^{\dagger}$ Present address:

Kyle M. Meyer,

Department of Integrative Biology, University of California, Berkeley,

Berkeley, CA, United States

Specialty section

This article was submitted to Terrestrial Microbiology, a section of the journal

Frontiers in Microbiology

Received: 07 March 2019

Accepted: 22 August 2019

Published: 11 September 2019

Citation:

Meyer KM, Petersen IAB, Tobi E, Korte L and Bohannan BJM (2019)

Use of RNA and DNA to Identify Mechanisms of Bacterial Community

Homogenization.

Front. Microbiol. 10:2066.

doi: 10.3389/fmicb.2019.02066

\section{Use of RNA and DNA to Identify Mechanisms of Bacterial Community Homogenization}

\author{
Kyle M. Meyer ${ }^{1 *}$, Ian A. B. Petersen ${ }^{1}$, Elie Tobi ${ }^{2}$, Lisa Korte ${ }^{2}$ and \\ Brendan J. M. Bohannan ${ }^{1}$
}

${ }^{1}$ Department of Biology, Institute of Ecology and Evolution, University of Oregon, Eugene, OR, United States, ${ }^{2}$ Smithsonian

Institute, Gabon Biodiversity Program, Gamba, Gabon

Biotic homogenization, i.e., the increase in community similarity through time or space, is a commonly observed response following conversion of native ecosystems to agriculture, but our understanding of the ecological mechanisms underlying this process is limited for bacterial communities. Identifying mechanisms of bacterial community homogenization following rapid environmental change may be complicated by the fact only a minority of taxa is active at any time. Here we used RNA- and DNAbased metabarcoding to distinguish putatively active taxa in the bacterial community from inactive taxa. We asked how soil bacterial communities respond to land use change following a rapid transition from rainforest to agriculture in the Congo Basin using a chronosequence that spans from roughly 1 week following slash-and-burn to an active plantation roughly 1.5 years post-conversion. Our results indicate that the magnitude of community homogenization is larger in the RNA-inferred community than the DNA-inferred perspective. We show that as the soil environment changes, the RNA-inferred community structure tracks environmental variation and loses spatial structure. The DNA-inferred community does not respond to environmental variability to the same degree, and is instead homogenized by a subset of taxa that is shared between forest and conversion sites. Our results suggest that complementing DNAbased surveys with RNA can provide insights into the way bacterial communities respond to environmental change.

Keywords: metabarcoding, land use change, tropical rain forests, homogenization, tropics

\section{INTRODUCTION}

One of the most rampant forms of environmental change today is land use change following the conversion of tropical rainforests to agriculture (Houghton, 1994; Dirzo and Raven, 2003; Foley et al., 2005; Laurance et al., 2014). Both above- and below-ground communities experience species loss and community change at unprecedented rates following land use change (Hooper et al., 2012; Rodrigues et al., 2013; Mueller et al., 2014), and this is of concern because tropical rainforests are some of the most diverse and productive ecosystems on the planet (Dirzo and Raven, 2003). Predicting community responses to tropical land use change is a priority if we are to better understand how human activities will impact species loss and biogeochemical cycling 
(Cardinale et al., 2012; Bell and Tylianakis, 2016), but in order to gain such a level of predictability we must better understand the mechanisms underlying community change.

Biotic homogenization refers to the process by which genetic, taxonomic, or functional similarities of biotic communities increase over time or space (Olden and Rooney, 2006). Biotic homogenization is a major consequence of land use change (McKinney and Lockwood, 1999). This process can be driven by two primary mechanisms: (1) the loss of environmental heterogeneity, which drives subsequent community convergence (Christensen and Peet, 1984; Lepš, 1991), and/or (2) increased rates of biotic mixing, which can be driven by the breakdown of dispersal barriers, invasion of exotic taxa, or the range expansion of existing taxa (Olden and Poff, 2003; Olden and Rooney, 2006). These mechanisms have both been implicated in the homogenization of microbial communities following land use change (Rodrigues et al., 2013; Mcguire et al., 2015; Gossner et al., 2016; Mueller et al., 2016, 2014; Tripathi et al., 2016), but it remains unknown how choices related to community inference method or analysis could influence our mechanistic conclusions.

Understanding mechanisms of biotic homogenization may be complicated by the fact that only a minority of soil taxa is active at any given point in time (Lennon and Jones, 2011; Blagodatskaya and Kuzyakov, 2013). It is possible to distinguish active community members by assaying 16S rRNA (as opposed to the 16S rRNA gene) (Jones and Lennon, 2010; Kamke et al., 2010; Baldrian et al., 2012; Romanowicz et al., 2016). This methodology could provide new insights into microbial community homogenization. For example, targeting active taxa could help us hone in on the portion of the community that is interacting with the environment and thus who is likely to respond immediately to environmental changes. Secondly, if land use change is driving increased rates of biotic mixing, studying the active fraction could help us distinguish who is actually growing and becoming established from those who are simply arriving. This distinction may be especially important when considering that most of our existing knowledge on microbial homogenization comes from DNA-based diversity studies [e.g., Rodrigues et al., 2013; Navarrete et al., 2015b; Wood et al., 2015)] that do not distinguish active from inactive taxa. Some controversy, however, surrounds the use of rRNA to infer microbial activity levels. For example, rRNA concentration and growth rate and/or activity are not consistently correlated across taxa, and certain taxa can still contain ribosomes while dormant [see Blazewicz et al. (2013)]. The use of 16S rRNA: 16S rRNA gene ratios of taxa has also been shown to not correlate well with activity levels inferred by other means (Papp et al., 2018a,b), and can be biased by extracellular environmental DNA (Dlott et al., 2015), taxon-specific dormancy strategies and sampling extent (Steven et al., 2017). While the use of rRNA:rRNA gene ratios may be problematic, several studies have shown that communities inferred using rRNA more closely correlate with environmental variability (Zhang et al., 2014), and respond more strongly to seasonal variation (Barnard et al., 2013) and nutrient pulses (Freedman et al., 2015) than communities inferred using the rRNA gene, which is consistent with the idea that the rRNA content of a community is at least enriched with active members. Thus, RNA-based community inference may provide unique foundational insights into the mechanisms underlying community change, but to date few have sought to make this comparison.

Although there have been several studies comparing established agricultural sites to pristine ecosystems, few have sought to include sites that represent the intermediary stages of conversion (e.g., recently slash-and-burned areas). By including more sites along the conversion continuum, we can increase the resolution by which we understand this process and diagnose when the largest losses of biodiversity occur, as well as pinpoint management practices that could be targeted for improvement. Moreover, expanding sampling efforts geographically, i.e., to under-represented regions, could disentangle common patterns from site-specific ones. This is especially important when considering that much of what we know about microbial responses to tropical land use change comes from studies in the Amazon Basin (Cenciani et al., 2009; Rodrigues et al., 2013; Mirza et al., 2014; Paula et al., 2014; Navarrete et al., 2015a,b; de Carvalho et al., 2016; Hamaoui et al., 2016; Mueller et al., 2016, 2014; Meyer et al., 2017). Comparatively fewer studies have been performed in the forests of Indonesia (Lee-Cruz et al., 2013; Mcguire et al., 2015; Tripathi et al., 2016; Wood et al., 2017) or Central and West Africa (Sul et al., 2013; Alele et al., 2014; Wood et al., 2015), and to our knowledge, none have been performed in the Congo Basin.

Here we examine soil bacterial community change along a land use change gradient in the Congo Basin, the world's second largest rainforest (Wilkie and Laporte, 2001). Our work expands on past studies by performing paired RNA/DNA co-extraction from each sample in order to ask whether the putatively active fraction of the community elicits a different response to land use change than the total community. Our gradient includes a site that had very recently been cut and burned, which allows us to use RNA/DNA in a system that is experiencing rapid and intense change. We test the following hypotheses: (1) that converted (burned and plantation) sites will exhibit decreased rates of spatial turnover of both the RNA- and DNA-inferred bacterial communities, as well as a decrease in taxonomic richness, (2) that changes to the soil chemical environment will play a stronger role in shaping the RNA-inferred community than the DNA-inferred community, and (3) that biotic invasions or range expansions contribute to community homogenization.

\section{MATERIALS AND METHODS}

\section{Sampling Site}

Central Africa contains up to 1.8 million $\mathrm{km}^{2}$ of contiguous tropical moist forest, making it the second largest block of tropical moist forest in the world, after the Amazon Basin (Wilkie and Laporte, 2001). Central African rainforest is renowned for its exceptionally high levels of biodiversity and endemism (White, 2001; Lee et al., 2006; Butler and Laurance, 2008) and faces threat of deforestation (Naughton-Treves and Weber, 2001), although recent forest conservation efforts are proving fruitful (Ernst et al., 2013; Sannier et al., 2014). The nation of Gabon contains more 
than $10 \%$ of the contiguous tropical moist forest in Africa (Wilkie and Laporte, 2001; Lee et al., 2006), and the majority of these forested areas are either currently leased as long-term logging concessions or are at risk from agricultural conversion (Collomb et al., 2000; Laurance et al., 2006; Lee et al., 2006).

Our study was performed in southwestern Gabon near the Gamba complex of protected areas (Lee et al., 2006). Soils in this area are classified as Dystic Fluvisol (Jones et al., 2013). Agricultural conversion in this region follows slash-and-burn practices that are typical of most tropical regions whereby forests are selectively logged and the remaining vegetation is burned. The following season, plantation crops (typically manioc or banana) are planted and harvested for 1-3 years. Following the last harvest, plantations are abandoned and secondary forest develops. We selected sites representative of this cycle including a recently burned site (roughly 1 week post burn), an active manioc and banana plantation (roughly 1.5 years old), and an adjacent intact forest (with no reported history of logging from locals), which allows us to break down the conversion process into two steps, providing more resolution. Sites were all within $1 \mathrm{~km}$ of each other and can be found at the following coordinates: burned site $\left(2^{\circ} 44^{\prime} 48^{\prime \prime} \mathrm{S}, 10^{\circ} 8^{\prime} 54^{\prime \prime} \mathrm{E}\right)$, plantation $\left(2^{\circ} 44^{\prime} 58^{\prime \prime} \mathrm{S}, 10^{\circ} 8^{\prime}\right.$ $\left.51^{\prime \prime} \mathrm{E}\right)$, and adjacent forest $\left(2^{\circ} 44^{\prime} 46^{\prime \prime} \mathrm{S}, 10^{\circ} 8^{\prime} 52^{\prime \prime} \mathrm{E}\right)$.

\section{Sampling Design and Sample Collection}

This study was designed specifically to understand differences between RNA- and DNA-inferred communities within these sites, not to identify general effects of land use change on Congo Basin ecosystems, which would be better-tested using replication at the land type level (Hurlbert, 1984). Limited access to sites and logistical challenges with sampling in this area required that we extensively survey one site within each of three land types, rather than performing higher levels of replication on fewer, land types. This design is appropriate for asking how these sites differ from one another, or how RNA- and DNAinferred community composition or diversity patterns differ from one another (Oksanen, 2001; Schank and Koehnle, 2009; Colegrave and Ruxton, 2018). Regarding inferences about general microbial responses to land use change in the Congo Basin, this study would be considered a case study (Hurlbert, 1984), whereby our results may be suggestive of broader patterns, but such patterns should be corroborated using a design with land type replication.

Soil samples were taken at the end of the Gabonese dry season (September 24-27, 2013). We established plots within each of the aforementioned sites. Each plot consisted of a nested sampling scheme (Rodrigues et al., 2013) where a $100 \mathrm{~m} \times 100 \mathrm{~m}$ quadrat was established, with $10 \mathrm{~m} \times 10 \mathrm{~m}, 1 \mathrm{~m} \times 1 \mathrm{~m}, 0.1 \mathrm{~m} \times 0.1 \mathrm{~m}$ quadrats nested within each, giving high coverage of a range of spatial scales (Figure 1). Soil cores were taken to a depth of $15 \mathrm{~cm}$ (after removal of leaf litter) from the corners of each quadrat ( $N=13$ samples per site, $N=39$ samples total). For each point, 3 cores were taken, homogenized, and then subsampled. From the homogenized mixture, $3 \mathrm{ml}$ (approximately $1 \mathrm{~g}$ ) of soil was added to $9 \mathrm{ml}$ Lifeguard solution (Mobio, California, United States) in the field, then transported cold and stored at $-80^{\circ} \mathrm{C}$ in order to stabilize nucleotides for later extraction.
Our spatially explicit design allows for the estimation of spatial turnover (beta diversity) (Anderson et al., 2011).

\section{Extraction, PCR, and Sequencing}

Soil RNA and DNA were co-extracted from Lifeguard-preserved soil samples using MoBio's Powersoil RNA Isolation kit with the DNA Elution Accessory Kit (MoBio, California, United States) following manufacturer's instructions. Extractions were quantified using Qubit (Life Technologies, United States). RNA was reverse transcribed to cDNA using Superscript III firststrand reverse transcriptase and random hexamer primers (Life Technologies, United States).

The V3 and V4 region of the $16 \mathrm{~S}$ rRNA gene of the DNA and cDNA were PCR amplified using the primers 319F and 806R (primarily targeting Bacteria, with limited coverage of Archaea). Sequencing libraries were prepped using a two-step PCR with dual-indexing approach (Kozich et al., 2013; Fadrosh et al., 2014). In short, for the first round of amplification $25 \mu$ l reactions of $5 \mu \mathrm{l}$ X Phusion HF buffer, $0.5 \mu \mathrm{l}$ dNTPs, $1.25 \mu \mathrm{l}$ of each primer, $0.25 \mu \mathrm{l}$ of Phusion DNA polymerase, $16.75 \mu \mathrm{l} \mathrm{H}_{2} \mathrm{O}$, and $2 \mu 1$ DNA template were combined and amplified for 22 cycles. Round 1 products were cleaned using Agencourt AMPure XP (Beckman Coulter, California, United States) then amplified for an additional 6 cycles using Phusion HiFi to add the sequences required for cluster formation on the Illumina flowcell. The final library was sent to the Dana-Farber Cancer Institute Molecular Biology Core Facilities for 300 paired-end (PE) sequencing on the Illumina MiSeq platform.

\section{Soil Chemical Analysis}

Soil chemical parameters were measured in each soil core (by A \& L Western Agricultural Lab, Modesto, CA, United States), including percent organic matter [loss on ignition (Dean, 1974)], extractable phosphorus [Weak Bray (Kamprath and Watson, 1980) and sodium bicarbonate (Olsen, 1954)], extractable cations $[\mathrm{K}, \mathrm{Mg}, \mathrm{Ca}, \mathrm{Na}$, and by ammonium acetate extraction (Simard, 1993)], nitrate-N, sulfate-S (Fox et al., 1964), pH, buffer $\mathrm{pH}$, cation exchange capacity [CEC, (Chapman, 1965)], and percent cation saturation. Pearson's correlation tests were performed on all pairs of chemical parameters to test for autocorrelation and reduce the number of chemical variables used in our models. Pairs of variables that were highly correlated $\left(R^{2}>0.6\right.$, $P<0.05)$ were reduced to a single variable so as to not inflate estimates of environmental similarity among samples (described below). The final suite of chemical analyses used after paring down correlated variables included percent organic matter, extractable phosphorus (Weak Bray), $\mathrm{pH}$, extractable $\mathrm{K}$, CEC, nitrate- $\mathrm{N}$, and $\mathrm{S}$.

\section{Bioinformatics and Statistical Analysis}

Paired end reads were combined then demultiplexed in QIIME (Caporaso et al., 2010) before quality filtering. Primers were removed, then UPARSE was used to quality filter and truncate sequences (416 bp, EE 0.5) (Edgar, 2013). Sequences were retained only if they had an identical duplicate in the database. Operational taxonomic units (OTUs) were clustered de novo at $97 \%$ similarity using USEARCH (Edgar, 2010). OTUs were 


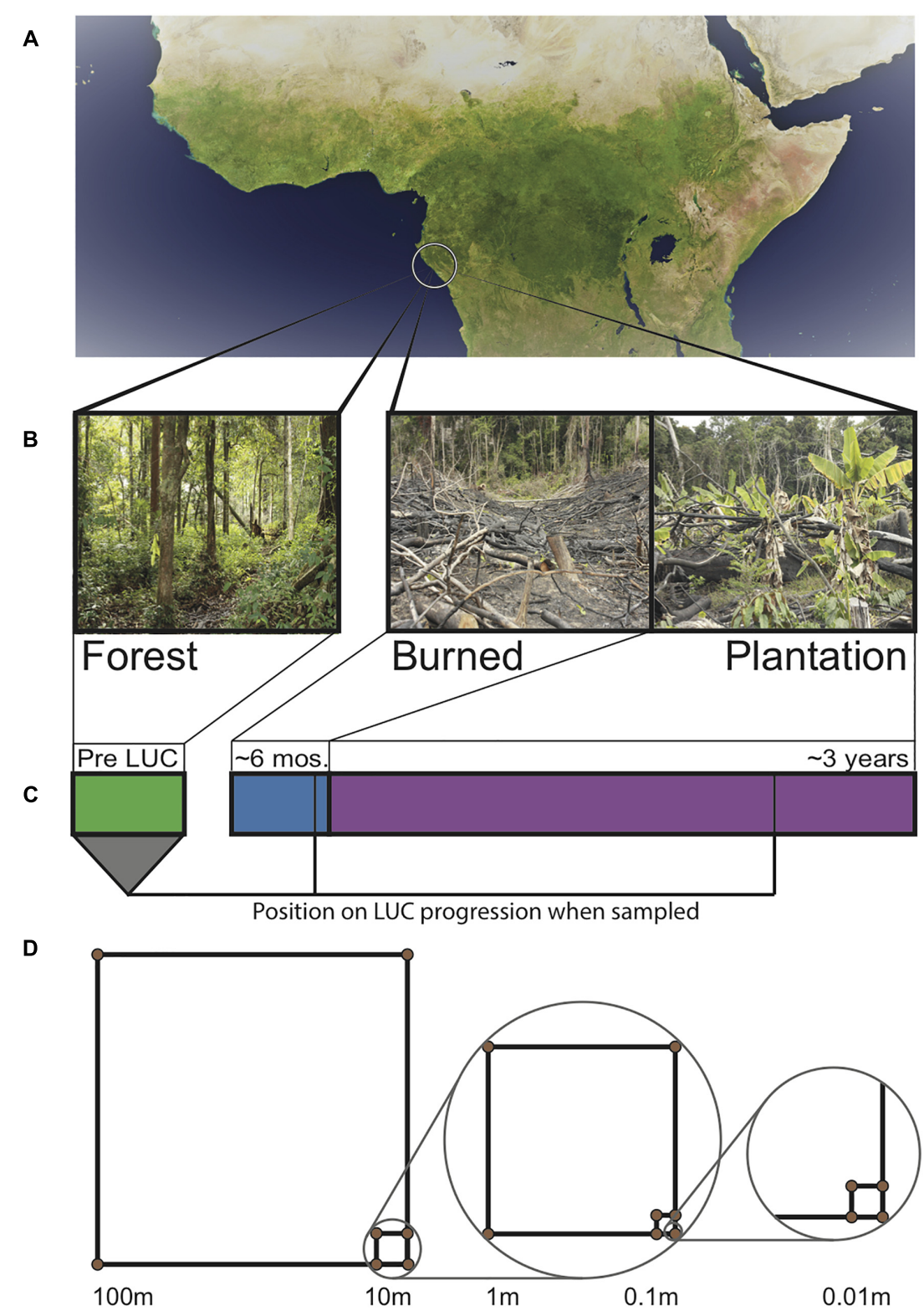

FIGURE 1 | Sampling design across Gabonese chronosequence of land use change (LUC). (A) Satellite image of the Congo Basin with location of sampling sites circled. (B) Images of field sites from which samples were taken. (C) Timeline of land use change. Bar width is proportional to the amount of time a site typically spends in each stage. Lines indicate when samples were collected. (D) Spatially explicit nested sampling scheme used in each land type. Samples were taken at the corners of each square.

checked for chimeras using the gold database in USEARCH. To assign taxonomy, we used the repset from UPARSE in QIIME using greengenes version 13_5 (RDP classifier algorithm). Finally, we averaged 100 rarefactions at a depth of 3790 counts per sample for each community inference (RNA or DNA) and each land type (forest, burned, or plantation) to achieve approximately equal sampling depth across comparisons, which excluded three samples in the DNA-inferred communities (two in the forest and one in the plantation).

Statistical analyses were performed in the $\mathrm{R}$ platform (R Core Team, 2018). Canberra pairwise community distances were calculated using the vegdist function in the package "vegan" (Oksanen et al., 2015). Canberra was chosen because of its incorporation of abundance data, sensitivity to rare community members (Jost et al., 2011), and ability to detect ecological patterns even in instances of relatively low sampling extent (Kuczynski et al., 2010). Rates of community spatial turnover were estimated by regressing pairwise community similarity (1- Canberra distance) against pairwise geographic distance between samples (Nekola and White, 1999). We used a similar regression approach between community similarity and environmental similarity to estimate the relationship between 
community turnover and environmental turnover. Pairwise soil environmental similarity was calculated using 1- Gower dissimilarity (Gower, 1971; Gower and Legendre, 1986) using the daisy function in the package "cluster" in R (Maechler et al., 2016). Gower dissimilarity was chosen because it can incorporate and compare different classes or scales of data (Legendre and Legendre, 1998). Mantel tests were used to test for significant associations between geographic, community, and environmental distance, and partial Mantel tests were used to estimate the relative contribution of environmental distance and geographic distance on variation in community dissimilarity in the "vegan" package in R. Differences in average pairwise similarity across land types were assessed using a oneway ANOVA after verifying normal distribution of data. Post hoc comparisons of group means were made using Tukey's HSD. Differences in pairwise similarity levels between RNAand DNA-inferred communities were assessed using a twotailed Student's $t$-test. Distance-decay slopes were compared using the function diffslope (package "simba") (Jurasinski and Retzer, 2012). This function employs a randomization approach across samples from each dataset and compares the difference in slope to the original configuration of samples. The $p$-values computed are the ratio between the number of cases where the differences in slope exceed the difference in slope of the initial configuration and the number of permutations (1000). We used the DESeq2 function (Love et al., 2014) in $\mathrm{R}$ to identify differentially abundant taxa in one land type vs. another. Low abundance samples were excluded prior to performing DESeq2 analysis. This function uses a generalized linear model (family negative binomial) to estimate dispersion and $\log _{2}$-fold change in relative abundance of individual taxa. Taxa were deemed differentially abundant if they had a positive $\log _{2}$-fold change and $P_{a d j}<0.05$. Figures were either created using base $\mathrm{R}$ or the "ggplot2" package (Wickham, 2009).

We developed several community analysis approaches to investigate whether biotic invasion or range expansion contribute to biotic homogenization. Taxa found in a conversion land type (i.e., the burned or plantation site), but not the forest, were considered "newcomers." In other words, newcomers included any taxa that were not detected in the forest, but were detected in the conversion sites. We removed these taxa from the community matrix, equalized sampling extent (using rarefaction), and then re-ran analyses of pairwise community similarity levels and distance-decay (described above). The expectation was that if they contribute to homogenization (increased community similarity), then their removal should decrease pairwise community similarity levels. We took an analogous approach to ask if range expansion of forestassociated taxa (referred to as "bloomer" taxa) contributes to biotic homogenization. To do so, we identified taxa that were differentially abundant in converted sites relative to the forest site (described above), then removed them from the community matrix of the converted site, and re-assessed community similarity levels and distance-decay. The expectation, as above, was that if these taxa contribute to homogenization, then their removal should render the communities less similar.

\section{RESULTS}

\section{Soil Bacterial Community Structure Differs by Land Use}

We first asked whether bacterial community structure differed by land use for RNA- and DNA-inferred communities by performing a PERMANOVA on OTU-level community Canberra distance, with land type as the independent variable. Land type differences in community composition were significant for both DNA- and RNA-inferred communities (DNA-inferred $F_{2,35}=2.35, R^{2}=0.125, p<0.001$, RNA-inferred $F_{2,37}=2.676$, $\left.R^{2}=0.133, p<0.001\right)$. These findings were also consistent at higher taxonomic levels (Supplementary Figures 1-3). The most pronounced differences at the phylum level were lower relative abundances of Acidobacteria in the burned site compared to the forest and plantation sites [burned site (DNA): $6.86 \pm 0.78 \%$, forest site (DNA): $11.07 \pm 1.73 \%$, plantation site (DNA): $11.30 \pm 1.32 \%$ ], and higher relative abundances of Actinobacteria in the burned site relative to forest and plantation sites [burned site (DNA): $10.86 \pm 1.16 \%$, forest site (DNA): $7.69 \pm 1.40 \%$, plantation site (DNA): $8.73 \pm 1.33 \%$ ], and this trend was consistent whether communities were inferred via DNA or RNA (Supplementary Figure 1). OTU-level richness also differed by land type $\left(F_{2,70}=8.26, p<0.001\right)$, but not community inference method $(p=0.80)$, with the burned site being significantly lower in richness than the forest or plantation sites (Tukey's HSD $p<0.01$, for both comparisons, Supplementary Figure 4).

\section{Evidence of Biotic Homogenization Following Land Use Change}

We asked whether soil bacterial communities in the sites undergoing agricultural conversion were on average more similar to each other, relative to the communities found in the forest. The RNA-inferred community showed a strong trend toward homogenization across sites $\left(F_{2,219}=23.33\right.$, $p<0.001$ ), with average pairwise similarity increasing over the progression of agricultural development across our sites (i.e., the chronosequence, Canberra: forest mean: $0.289 \pm 0.008$, burned mean: $0.327 \pm 0.004$, plantation mean: 0.340, \pm 0.004$)$. The DNA-inferred community also differed in pairwise similarity across sites $\left(F_{2,184}=4.54, p=0.012\right)$, but this trend was less pronounced, and similarity levels were only significantly higher in the burned site (Canberra: forest mean: $0.268 \pm 0.011$, burned mean: $0.301 \pm 0.006$, and plantation mean: $0.288 \pm 0.006$ ) RNA-inferred community similarity was significantly higher than DNA-inferred community similarity in the burned site $(t=3.87$, $p<0.001)$ and the plantation site $(t=7.45, p<0.001)$, but not the forest site ( $p=0.144$; Figure 2).

While levels of average pairwise community similarity tended to increase across the chronosequence, the spatial signal of community similarity (i.e., spatial turnover) tended to either weaken or disappear. Both the RNA-inferred and DNA-inferred communities showed distance-decay relationships in the forest (Mantel $r_{R N A}=0.846, p=0.003$, slope $=-0.027$; Mantel $\mathrm{r}_{D N A}=0.697, p=0.02$, slope $=-0.028$, Figures 3A,B) where 


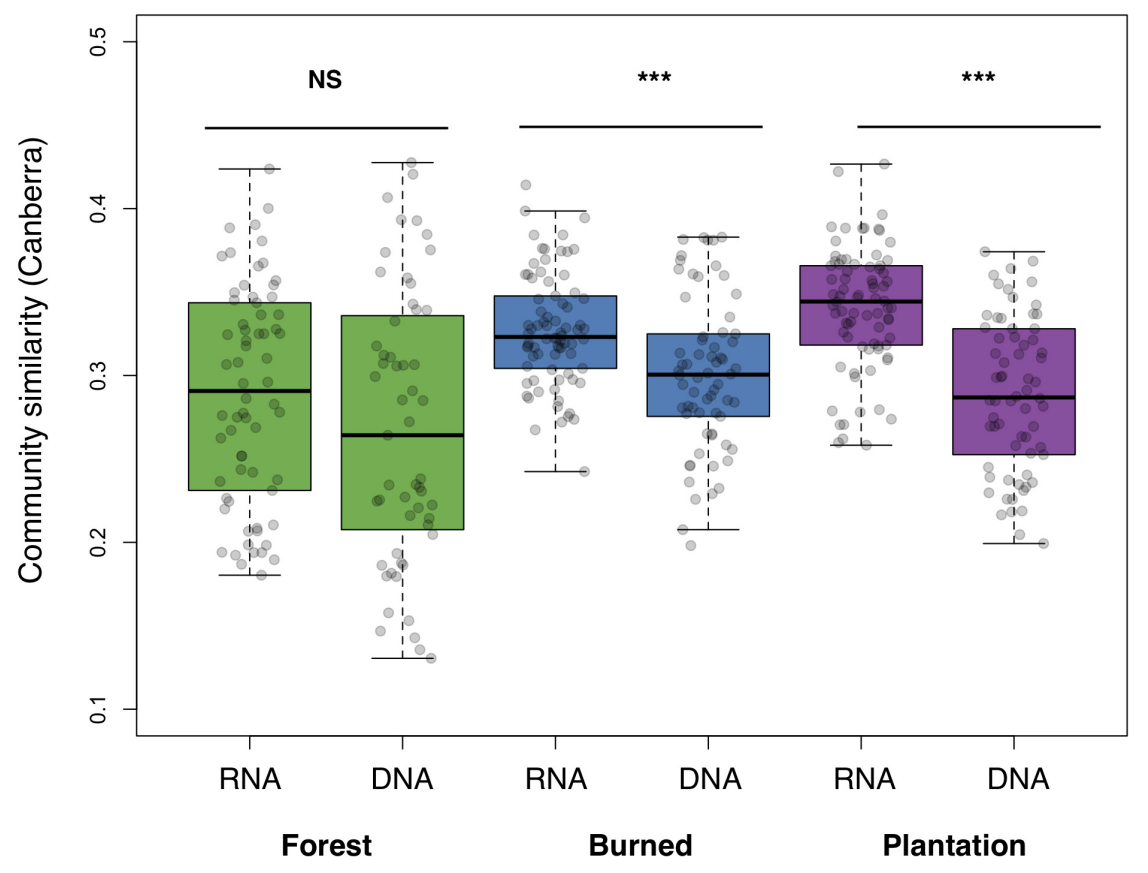

FIGURE 2 | Average pairwise similarity (1 - Canberra distance) of the RNA- and DNA-inferred communities, across the forest, burned, and plantation sites. Differences between RNA- and DNA-inferred communities assessed using two-tailed Student's t-test, ${ }^{* * *} p<0.001$.

communities in close proximity tended to exhibit higher levels of similarity than communities farther apart. The RNA-inferred community showed no significant distance-decay relationship in either the burned site (Mantel $r=0.247, p=0.127$ ) or the plantation site (Mantel $r=0.431, p=0.063$ ). The DNA-inferred community showed a weak distance-decay relationship in the burned site with a threefold decrease in slope from the forest (Mantel $r=0.474, p=0.048$, slope $=-0.009$ ), and no significant distance-decay relationship in the plantation (Mantel $r=0.232$, $p=0.163$ ). Thus, both windows into the community indicated shifts toward spatial homogenization, but this trend was more pronounced in the RNA-inferred fraction of the community.

\section{Soil Environment Gains Variation, but Loses Spatial Structure Following Conversion}

Soil chemical profiles exhibited a number of changes across land types including increases in $\mathrm{pH}$ and phosphorus and decreases in percent organic matter throughout the chronosequence, and elevated cation exchange capacity and levels of nitrate-N, sulfur, and potassium in the burned site (Supplementary Table 1). When we consider the differentiation of soil chemical profiles within land types, we see that levels of average environmental pairwise similarity (1-Gower distance) decrease from the forest to the burned and plantation sites $\left(F_{2,231}=4.22, p=0.016\right.$, Supplementary Figure 5), indicating that soils within a land type are more dissimilar from one another. Similar to the spatial structure of the communities, the spatial structure of environmental variation also changes across the chronosequence. Forest soils show a significant environmental distance-decay relationship (Mantel $r=0.729, p=0.01$, slope $=-0.052$ ), where samples closer in proximity tend to be more similar in environmental conditions. This relationship was not significant in the burned site (Mantel $r=0.338, p=0.068$ ), and was comparatively weaker in the plantation relative to the forest (Mantel $r=0.465, p=0.01$ ) and showed a shallower distancedecay slope (slope $=-0.027$, difference in slope $=-0.025$, $p=0.001$ ). Thus burning and planting seem to introduce environmental heterogeneity, but this heterogeneity tends to show little to no spatial structure.

\section{Environmental Heterogeneity Continues to Influence RNA-Inferred (and Not DNA-Inferred) Community Turnover, Despite Loss of Spatial Structure}

We asked whether the loss of spatial structure of the soil chemical environment could be contributing to the loss of spatial turnover in the microbial community. To do so, we regressed pairwise community similarity (1-Canberra distance) against pairwise environmental similarity (1-Gower distance) for both the RNA- and DNA-inferred communities. In the forest site, both RNA- and DNA-inferred community similarity levels were positively correlated with environmental similarity (Figures 4A,B), even after accounting for differences due to geographic distance (Table 1), suggesting samples with similar environmental (chemical) conditions tended to harbor similar communities. When we look at the burned site and plantation site, however, this relationship persists for the RNAinferred community, but disappears for the DNA-inferred community (Table 1), suggesting that the spatial homogenization 
A RNA-inferred communities
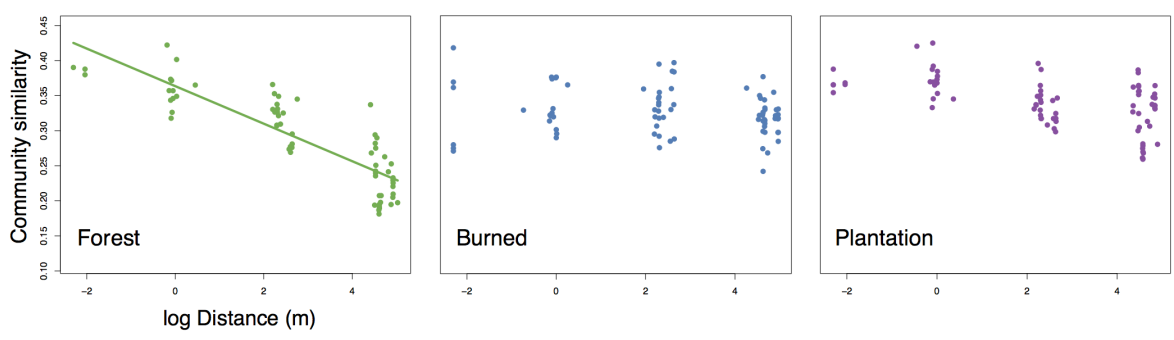

B DNA-inferred communities
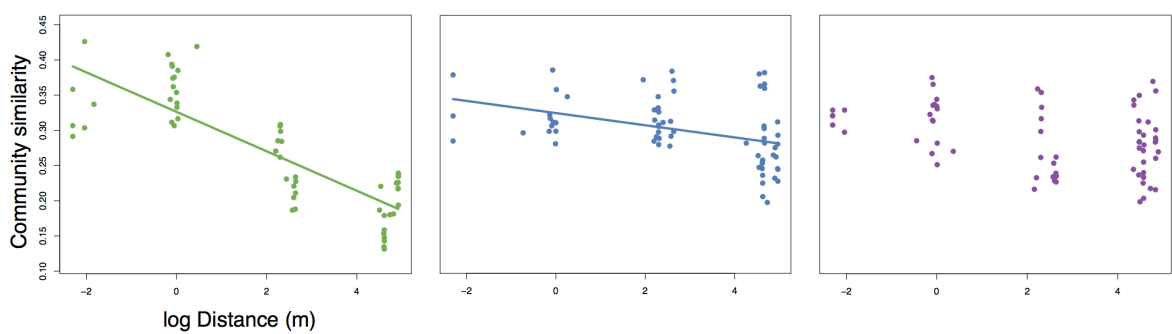

FIGURE 3 | Change (or loss) of distance-decay of community similarity for (A) RNA-inferred communities, and (B) DNA-inferred communities. Trend lines were drawn only for significant (Mantel $p<0.05$ ) associations.

of the DNA-inferred community may be driven by other mechanisms besides soil chemical homogenization. Thus as environmental heterogeneity loses its spatial structure, the RNA-inferred community similarity levels continue to vary with this heterogeneity and lose spatial structure, while the DNA-inferred community becomes decoupled from levels of environmental variation.

\section{No Evidence for Biotic Invasions Contributing to Homogenization}

We next tested the hypothesis that the introduction of "newcomer" taxa (i.e., those that were not previously present) was driving community homogenization. 390 of the 1545 DNAinferred community members in the burned site $(25.2 \%$ of OTUs, representing on average $1.8 \pm 1.1 \%$ of the community) were not detected in the forest site. 570 of the 1804 DNAinferred community members in the plantation site $(31.7 \%$ of OTUs, representing on average $1.8 \pm 0.8 \%$ of the community) were not detected in the forest site. These taxa were not particularly geographically widespread (average occurrence frequency Burn newcomers $_{\text {notation }}$ newcomers $=0.25 \pm 0.010$ ). Moreover, only $53.6 \%$ of the newcomer taxa in the burned site DNA-inferred community were detected in the RNA fraction of that site, and $63.5 \%$ of the newcomer taxa in the plantation site DNA-inferred community were detected in the RNA fraction of that site, indicating that many newcomers are not active. We tested whether the newcomer taxa were driving higher estimates of community similarity by removing them from the community matrix, equalizing sampling extent across samples (using rarefaction), then recalculating community similarity (1-Canberra distance). Our expectation was that the removal of newcomers from the community matrix would render communities more dissimilar (i.e., less homogenized). This was not the case. Removal of the newcomer taxa from the burned site community matrices actually increased community similarity of the DNA-inferred community (Table 2). Removal of newcomers also did not render a significant spatial signal for the DNA-inferred communities (Table 2). This was also the case for the plantation, where the removal of the newcomer taxa increased community similarity for the DNA-inferred communities (Table 2), and left no spatial signal (Table 2). Thus we have no evidence to suggest that the homogenization of the DNA-inferred community is driven by the arrival of newcomer taxa.

We found similar results when we performed these same analyses on the RNA-inferred communities. Newcomer taxa comprised a similarly small proportion of the communities in the burned $(2.2 \pm 1.8 \%)$ and plantation sites $(2.1 \pm 0.79 \%)$. These taxa were also not particularly widespread, with average occurrence frequencies in the burned site of $0.26 \pm 0.16$ and $0.25 \pm 0.01$ in the plantation site. Similar to the DNAinferred community, the removal of newcomer taxa from the RNA-inferred community rendered higher levels of average pairwise similarity in the burned site community and the plantation site community (Table 2), suggesting that their abundances are not driving levels of community similarity. Lastly, the removal of newcomers from the RNAinferred community did not render significant relationships with geographic distance (Table 2), indicating that they do not play a role in community spatial homogenization. Hence we have no evidence to support the hypothesis that increased levels of biotic homogenization are being driven by the arrival of newcomer taxa, and in fact, 


\section{A RNA-inferred communities}
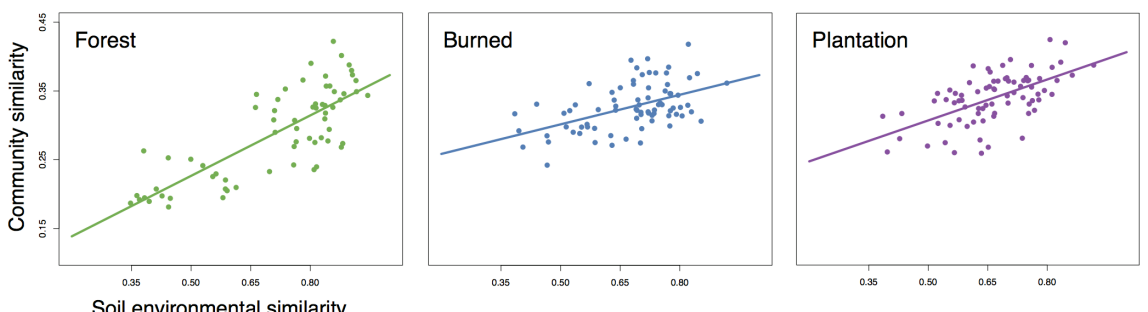

B DNA-inferred communities
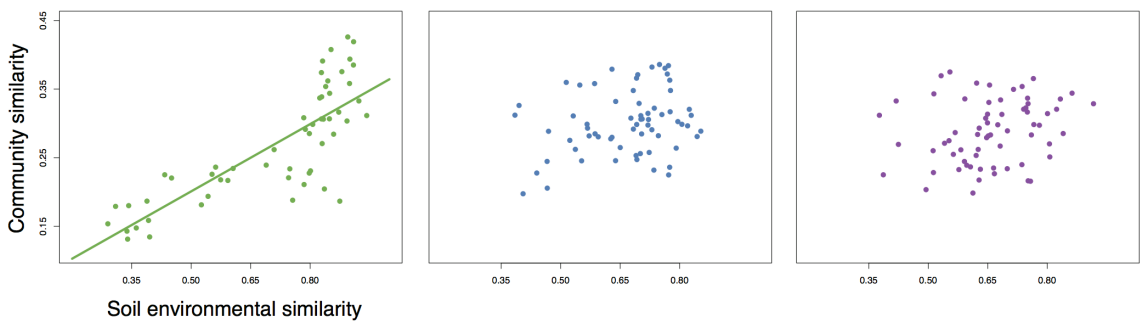

FIGURE 4 | The relationship between community similarity and environmental similarity (1 - Gower dissimilarity) for (A) RNA-inferred communities, and (B) DNA-inferred communities. Trend lines were only drawn for significant (Mantel $p<0.05$ ) associations.

TABLE 1 | The influence of environmental similarity and geographic distance on RNA-inferred and DNA-inferred bacterial communities.

\begin{tabular}{llllll}
\hline & \multicolumn{2}{c}{ Env. Simil. } & & \multicolumn{2}{c}{ Geog. Dist. } \\
\cline { 2 - 3 } \cline { 5 - 6 } & \multicolumn{1}{c}{$\boldsymbol{r}$} & $\boldsymbol{P}$ & & \multicolumn{1}{c}{$\boldsymbol{r}$} & \multicolumn{1}{c}{$\boldsymbol{P}$} \\
\hline Forest RNA & $\mathbf{0 . 5 6}$ & $\mathbf{0 . 0 2 2}$ & & 0.409 & 0.088 \\
Forest DNA & $\mathbf{0 . 5 3 6}$ & $\mathbf{0 . 0 2 6}$ & & 0.168 & 0.208 \\
Burned RNA & $\mathbf{0 . 4 9 1}$ & $\mathbf{0 . 0 0 8}$ & & 0.05 & 0.392 \\
Burned DNA & 0.237 & 0.174 & & 0.338 & 0.07 \\
Plantation RNA & $\mathbf{0 . 5 7}$ & $\mathbf{0 . 0 0 1}$ & & 0.082 & 0.284 \\
Plantation DNA & 0.17 & 0.194 & & 0.124 & 0.267
\end{tabular}

Partial mantel test summary statistics showing (1) the effect of environmental similarity after removing the effect of geographic distance (Env. Simil.), and (2) the effect of geographic distance after removing the effect of environmental similarity (Geog. Dist.). P values estimated from 1000 permutations. Bold values indicate statistical significance $(p<0.05)$.

it appears that the newcomers contribute variation to the communities.

\section{Range Expansion of Forest-Associated Taxa Drive Loss of Community Variation}

Because soil bacterial communities in the forest tended to show high taxonomic overlap with the burned site and plantation site, we asked whether homogenization might rather be driven by changes to the relative abundance of certain taxa. We used DESeq2 -a generalized linear model with a negative binomial distribution- to identify "bloomer" taxa (i.e., those whose relative abundance significantly increased by land type). This approach identified 127 taxa that were differentially enriched in the DNA-inferred communities of the burned site relative to the forest (comprising on average $23.85 \pm 9.5 \%$ of the DNAinferred burned site community, and $6.43 \pm 2.6 \%$ of the DNA-inferred forest site community), and 192 taxa that were enriched in the plantation relative to the forest (comprising on average $26.89 \pm 10.3 \%$ of the DNA-inferred plantation site community, and $5.45 \pm 2.2 \%$ of the DNA-inferred forest site community). We removed these bloomer taxa from the community matrices, equalized sampling extent across samples (as described above), and re-calculated pairwise similarity levels within land types. The removal of these taxa from the burned site DNA-inferred community matrix rendered the communities less similar $\left(0.268 \pm 0.005\right.$ vs. $0.301 \pm 0.006, F_{2,196}=6.95$, $p=0.001$, Supplementary Figure 6A) and indistinguishable from the forest levels of similarity $(0.268 \pm 0.011$, Tukey's HSD $p_{a d j}=0.999$ ), indicating that their relative abundances are indeed contributing to the increased pairwise similarity of these communities. This was also the case in the plantation, where the removal of the bloomer taxa from the DNA-inferred community matrix also rendered the communities less similar $\left(0.253 \pm 0.005\right.$ vs. $0.288 \pm 0.006, F_{2,184}=6.15, p=0.003$, Supplementary Figure 6A) and indistinguishable from the forest levels of similarity $\left(0.268 \pm 0.011\right.$, Tukey's HSD $\left.p_{a d j}=0.300\right)$, further supporting the idea that these taxa are driving the increase in levels of pairwise similarity in impacted sites. Beyond decreasing levels of community variation, the bloomer taxa also collectively showed a wider spatial distribution in the sites in which they were more abundant (Burn: frequrn bloomers in for $=0.597 \pm 0.034$, frequrn bloomers in burn $=0.845 \pm 0.020$; Plantation: freq $q_{\text {plantation bloomers in } r}=0.484 \pm 0.027$, freq $q_{\text {plantation }}$ bloomers in plantation $=0.830 \pm 0.014$ ). When we test whether these taxa are driving the changes to spatial turnover, however, we do not detect a significant spatial signal for the burned (Mantel 
TABLE 2 | No evidence that newcomer taxa contribute to community homogenization in burned site or plantation site.

\begin{tabular}{|c|c|c|c|c|c|c|c|c|}
\hline & \multicolumn{4}{|c|}{ Burned } & \multicolumn{4}{|c|}{ Plantation } \\
\hline & \multicolumn{2}{|c|}{ RNA-inferred } & \multicolumn{2}{|c|}{ DNA-inferred } & \multicolumn{2}{|c|}{ RNA-inferred } & \multicolumn{2}{|c|}{ DNA-inferred } \\
\hline & $\begin{array}{c}\text { No } \\
\text { newcomers }\end{array}$ & All taxa & $\begin{array}{c}\text { No } \\
\text { newcomers }\end{array}$ & All taxa & $\begin{array}{c}\text { No } \\
\text { newcomers }\end{array}$ & All taxa & $\begin{array}{c}\text { No } \\
\text { newcomers }\end{array}$ & All taxa \\
\hline Similarity levels & $0.347 \pm 0.004$ & $0.327 \pm 0.004$ & $0.322 \pm 0.006$ & $0.301 \pm 0.006$ & $0.372 \pm 0.004$ & $0.340 \pm 0.004$ & $0.322 \pm 0.006$ & $0.288 \pm 0.006$ \\
\hline Mantel $r$ & $\begin{array}{l}r=0.231 \\
p=0.151\end{array}$ & $\begin{array}{l}r=0.247 \\
p=0.127\end{array}$ & $\begin{array}{l}r=0.407 \\
p=0.074\end{array}$ & $\begin{array}{l}r=0.474 \\
p=0.048\end{array}$ & $\begin{array}{c}r=0.452 \\
p=0.07\end{array}$ & $\begin{array}{l}r=0.431 \\
p=0.063\end{array}$ & $\begin{array}{l}r=0.22 \\
p=0.159\end{array}$ & $\begin{array}{l}r=0.232 \\
p=0.163\end{array}$ \\
\hline
\end{tabular}

Similarity levels reflect 1 - Canberra distances \pm standard error.

$r=0.345, p=0.08$ ) or plantation (Mantel $r=0.185, p=0.194$ ) sites, indicating that the weakening or loss of community spatial structure may be driven by additional factors.

The same suite of analyses yielded similar findings for the RNA-inferred communities. Bloomer taxa in the RNA-inferred community comprised on average $35.6 \pm 14.2 \%$ of the burned site RNA-inferred community $(6.92 \pm 4.0 \%$ of the forest site community), and $37.54 \pm 10.6 \%$ of the plantation site RNAinferred community ( $9.96 \pm 4.1 \%$ of the forest site community). As described above, we tested whether the bloomer taxa were contributing to the increased levels of pairwise similarity of the burned and plantation site. Similar to the DNA-inferred findings, the removal of bloomer taxa from the burned site RNA-inferred community matrix rendered the communities less similar $\left(0.306 \pm 0.004\right.$ vs. $0.327 \pm 0.003, F_{2,219}=12.95$, $p<0.001$, Supplementary Figure 6B) and indistinguishable from the forest levels of similarity $(0.290 \pm 0.008$, Tukey's HSD $\left.p_{a d j}=0.124\right)$, indicating that their relative abundances contribute to the increased pairwise similarity of these communities. This was also the case in the plantation, where the removal of the bloomer taxa from the RNA-inferred community matrix rendered the communities less similar $(0.311 \pm 0.004$ vs. $0.340 \pm 0.004, F_{2,219}=22.96, p<0.001$, Supplementary Figure 6B), but in this case similarity levels were still distinguishable from the forest levels of similarity $(0.290 \pm 0.008$, Tukey's HSD $\left.p_{a d j}=0.029\right)$. The RNA-inferred bloomer taxa also collectively showed a wider spatial distribution in the sites in which they were more abundant (Burn: frequrn bloomers in for $=0.566 \pm 0.04$, frequrn bloomers in burn $=0.860 \pm 0.022$; Plantation: freq plantation bloomers in for $=0.506 \pm 0.03$, freq $q_{\text {plantation }}$ bloomers in plantation $=0.854 \pm 0.015$ ), but when we test whether these taxa are driving the changes to spatial turnover we do not detect a significant spatial signal for the burned (Mantel $r=0.006, p=0.474$ ) or plantation (Mantel $r=0.413, p=0.082$ ) sites following their removal. Thus, the identification of bloomer taxa in the DNA- and RNA-inferred communities has helped to identify the fraction of the community that is contributing to higher levels of community pairwise similarity.

\section{DISCUSSION}

Conversion of tropical rainforest to agriculture is one of the leading drivers of biodiversity loss and biotic homogenization worldwide (Houghton, 1994; Dirzo and Raven, 2003; Foley et al., 2005; Laurance et al., 2014). Gaining a better understanding of the ecological mechanisms driving biotic homogenization is a priority if we are to predict or mitigate changes to communities or their ecosystem functions (Cardinale et al., 2012; Bell and Tylianakis, 2016). We used a spatially explicit design across a chronosequence of land use change in the Congo Basin to investigate mechanisms of community homogenization. We used two windows into the structure of soil bacterial communities: (1) 16S rRNA (RNA) community inference - which should enrich for the active fraction of the community, and (2) 16S rRNA gene (DNA) community inference - which includes both active and inactive members, as well as "relic" DNA from dead cells (Carini et al., 2016; Lennon et al., 2017). Our results fit into a broader context of other studies that emphasize the importance of using RNA alongside DNA to investigate the impacts of environmental change on microbial communities (Barnard et al., 2013; Freedman et al., 2015).

Ecosystems can develop spatially autocorrelated environmental conditions (i.e., a distance-decay in environmental similarity) through a combination of localized physical forces or community processes (Legendre, 1993). Slash-and-burn conversion in our system appears to disrupt this spatial structure, while introducing variation. This form of conversion is a relatively uniform type of disturbance, in that all the aboveground vegetation gets removed and burned across the landscape, which likely drives the loss of spatial structure of the soil environment. The intensity of fire across a landscape, however, is often patchy, depending on certain local factors such as, e.g., the amount of biomass, or levels of moisture. Thus this form of disturbance could introduce environmental variation that shows little coherent spatial structure. This insight is important when we consider the relationship between community structure and the environment.

Communities can be homogenized by two main mechanisms: (1) the homogenization of the environment driving convergence of communities (Christensen and Peet, 1984; Lepš, 1991), or (2) increased biotic mixing, driven by the breakdown of dispersal barriers and/or the range expansion of previously present taxa (McKinney and Lockwood, 1999; Olden and Poff, 2003; Dormann et al., 2007; Vellend et al., 2007; Rodrigues et al., 2013; Mueller et al., 2016). If community homogenization is driven by environmental homogenization, community turnover should continue to track environmental turnover, even when 
spatial structure is lost. We see this in our data when we infer community structure using RNA, but not DNA, suggesting that environmental spatial homogenization is likely a strong driver of the spatial homogenization of the RNA-inferred community. Other studies using DNA-inference have reported relationships between environmental conditions and community similarity (Griffiths et al., 2011; Ranjard et al., 2013; Hermans et al., 2017), but this relationship can be quite weak in heavily managed soils (Gumiere et al., 2016). One reason for the apparent differences between our studies and others may be that our sites represent a much more rapid period of land transition, and hence DNA-inferred communities (including inactive taxa) may have not yet been reshaped by the new soil conditions. The decoupling of responses in the RNA- and DNA-inferred communities could also represent differing levels of contribution from homogenization mechanisms. Our results suggest that taxa that are enriched in the burned site or plantation site relative to the forest are contributing to the loss of community variation (i.e., average pairwise dissimilarity) in those sites. Those taxa also collectively show wider spatial distributions (i.e., higher occurrence frequencies) in the disturbed sites relative to the forest. These findings are consistent with the idea of a range expansion, and the fact that we saw this trend in both the RNA- and DNA-inferred communities suggests that identifying this type of homogenization mechanism may not require RNA-based community inference. A similar pattern has been observed in Amazonian sites that have undergone conversion to cattle pasture, where prokaryotic taxa shared across forest and agricultural sites tended to be more widespread in the agricultural sites (Rodrigues et al., 2013), and fungal communities in agricultural sites tended to be enriched in generalist taxa that were more widespread (Mueller et al., 2016). Thus by distinguishing communities using RNA and DNA, we see that only part of the community seems to be responding to the environmental changes associated with conversion, while communities inferred via both methods appear be shaped by biotic factors such as the breakdown of dispersal barriers and/or the range expansion of certain taxa.

The use of $16 \mathrm{~S}$ rRNA as a proxy for activity has been the subject of recent controversy. Of particular concern are two main issues: the assignment of false positives [i.e., dormant taxa misidentified as active (Blazewicz et al., 2013)], and the inaccurate assessment of activity levels [e.g., driven by comparing ratios of the relative abundance of taxa in the RNA- vs. DNAinferred communities (Dlott et al., 2015; Steven et al., 2017; Papp et al., 2018a,b)]. The ribosomal content of a community, however, should be at least enriched with the taxa that are active and/or growing, and there are a number of studies that support the notion that rRNA-inference represents activity. For example, if the active fraction of a community is more likely to be interacting with the environment than the dormant fraction (which is likely avoiding the current environmental conditions), then we would expect a stronger correspondence between environmental conditions and community turnover in a community that is enriched in active taxa (Lennon and Jones, 2011). Indeed this has been shown both along a marine environmental gradient (Zhang et al., 2014) and a grassland soil system experiencing re-wetting following drought (Barnard et al., 2013). It has also been shown that $\mathrm{N}$-addition to forest soil elicits a stronger response in communities inferred from $16 \mathrm{~S}$ rRNA than rDNA (Freedman et al., 2015). Our results contribute to this narrative by showing that RNA-inferred community turnover persistently tracks environmental turnover, while this association is lost when inferring only with DNA. We also see that the RNA-inferred community shows a more pronounced loss of community variation and spatial structure than the DNA-inferred community. An important caveat is that our study, like other studies of highly complex soil communities, faces issues of under-sampling, and the extent to which our observations are influenced by sampling effort could be an important topic for future work. Thus while rRNA inference may have certain limitations, our results, alongside others, suggest that this method should be enriching for active taxa, and this can have important implications for both qualitative and quantitative conclusions, especially in systems with strong environmental gradients.

Tropical ecosystems are characterized by immense heterogeneity, and this could make the task of detecting general responses to land use change difficult. Two important steps toward gaining a better understanding of common microbial responses to tropical land use change include (1) expanding the breadth (i.e., the geographic representation) of regions sampled, and (2) increasing the resolution of our study systems (e.g., by including more sites along the conversion continuum). Our study allows us to ask whether commonalities exist between our findings and those reported from other tropical ecosystems undergoing land use change. The changes we see to the spatial structuring of communities (i.e., a diminished distance-decay relationship) are consistent with responses reported from the Amazon Basin (Rodrigues et al., 2013; Navarrete et al., 2015b). While our study was not replicated at the land type level-restricting our level of inference regarding how representative our findings are of other Congo Basin areasour results at least suggest that a diminished rate of community distance-decay may be common across tropical areas facing a similar threat. The method of conversion may be driving this similarity in microbial community response. The predominant method for converting tropical rainforests to agriculture is the use of slash-and-burn techniques (Laurance, 2015). By including a recently slash-and-burned site in our design, we have gained a rare glimpse into the impacts directly following the initial step in agricultural conversion. Already at this stage we see that the loss of community spatial structure (i.e., distance-decay) has occurred, suggesting that spatial homogenization could be driven by the act of conversion, rather than other management practices such as planting or crop choice. Thus by targeting a region that has otherwise not been sampled, and increasing the resolution by which we survey the conversion process, we have gained new insights that may help to elucidate common community responses to tropical land use change.

Considering the rate and magnitude by which tropical rainforests are being converted to agriculture (Laurance et al., 2014), gaining a mechanistic understanding of community responses to environmental change is imperative 
(Bell and Tylianakis, 2016). Future efforts could investigate whether the functional potential (i.e., gene content) or trait distributions of a community are similarly impacted by land use change (Louca et al., 2016; Meyer et al., 2017), or whether ecosystem functions (e.g., those involved in nutrient cycling or greenhouse gas emissions) are impacted by community homogenization. Our work highlights the importance of distinguishing between metabolic states of microbial community members, if we are to better understand community responses to environmental change. Lastly, our work demonstrates that trends in our system are consistent with those reported from geographically disparate areas (e.g., the Amazon Basin), suggesting that despite large differences between these areas, land use change may drive predictable community changes.

\section{DATA AVAILABILITY}

DNA and cDNA sequence FASTA files, OTU tables, soil environmental data, as well as the $\mathrm{R}$ script for analysis will be available for download from https://doi.org/10.6084/m9.figshare. 5930434.v1.

\section{AUTHOR CONTRIBUTIONS}

KM designed the experiment, collected and processed the samples, performed the analysis, and wrote the manuscript. $\mathrm{BB}$ designed the experiment, collected the samples, and wrote the manuscript. IP aided in analysis and contributed to the

\section{REFERENCES}

Alele, P. O., Sheil, D., Surget-Groba, Y., Lingling, S., and Cannon, C. H. (2014). How does conversion of natural tropical rainforest ecosystems affect soil bacterial and fungal communities in the Nile River watershed of Uganda? PloS One 9:e104818. doi: 10.1371/journal.pone.0104818

Anderson, M. J., Crist, T. O., Chase, J. M., Vellend, M., Inouye, B. D., Freestone, A. L., et al. (2011). Navigating the multiple meanings of $\beta$ diversity: a roadmap for the practicing ecologist. Ecol. Lett. 14, 19-28. doi: 10.1111/j.1461-0248.2010. 01552.x

Baldrian, P., Kolařík, M., Stursová, M., Kopecký, J., Valášková, V., Větrovský, T., et al. (2012). Active and total microbial communities in forest soil are largely different and highly stratified during decomposition. ISME J. 6, 248-258. doi: 10.1038/ismej.2011.95

Barnard, R. L., Osborne, C. A., and Firestone, M. K. (2013). Responses of soil bacterial and fungal communities to extreme desiccation and rewetting. ISME J. 7, 2229-2241. doi: 10.1038/ismej.2013.104

Bell, T., and Tylianakis, J. M. (2016). Microbes in the anthropocene: spillover of agriculturally selected bacteria and their impact on natural ecosystems. Proc. $R$. Soc. 283, 1-9.

Blagodatskaya, E., and Kuzyakov, Y. (2013). Active microorganisms in soil: critical review of estimation criteria and approaches. Soil Biol. Biochem. 67, 192-211. doi: 10.1016/j.soilbio.2013.08.024

Blazewicz, S. J., Barnard, R. L., Daly, R. A., and Firestone, M. K. (2013). Evaluating rRNA as an indicator of microbial activity in environmental communities: limitations and uses. ISME J. 7, 2061-2068. doi: 10.1038/ismej.2013.102

Butler, R. A., and Laurance, W. F. (2008). New strategies for conserving tropical forests. Trends Ecol. Evol. 23, 469-472. doi: 10.1016/j.tree.2008.05.006

Caporaso, J. G., Kuczynski, J., Stombaugh, J., Bittinger, K., Bushman, F. D., Costello, E. K., et al. (2010). QIIME allows analysis of high- throughput manuscript. ET and LK helped to design the experiment and collect the samples, and contributed to the manuscript.

\section{FUNDING}

The Smithsonian Conservation Biology Institute, the Gabon-Oregon Transnational Center on Environment and Development, and Shell Gabon provided the financial and logistical support. BB is grateful for the support of the National Science Foundation - Dimensions of Biodiversity (DEB 14422214).

\section{ACKNOWLEDGMENTS}

We thank the Government of Gabon, Centre National de la Recherche Scientifique et Technologique for permission (Permit $\mathrm{N}^{o}$ 866/MENESTFPRSCJS/CENAREST/CG/CAB) to conduct this study. We also thank P. Voua Otomo and A. Litona Boubeya for their help in collecting the samples. This manuscript has been released as a Pre-Print at BioRxiv: http://doi.org/10.1101/496679 (Meyer et al., 2018).

\section{SUPPLEMENTARY MATERIAL}

The Supplementary Material for this article can be found online at: https://www.frontiersin.org/articles/10.3389/fmicb. 2019.02066/full\#supplementary-material

community sequencing data intensity normalization improves color calling in SOLiD sequencing. Nat. Methods 7, 335-336. doi: 10.1038/NMETH.F.303

Cardinale, B. J., Duffy, J. E., Gonzalez, A., Hooper, D. U., Perrings, C., Venail, P., et al. (2012). Biodiversity loss and its impact on humanity. Nature 486, 59-67. doi: $10.1038 /$ nature 11148

Carini, P., Marsden, P. J., Leff, J. W., Morgan, E. E., Strickland, M. S., and Fierer, N. (2016). Relic DNA is abundant in soil and obscures estimates of soil microbial diversity. Nat. Microbiol. 2, 1-6. doi: 10.1038/nmicrobiol. 2016.242

Cenciani, K., Lambais, M. R., Cerri, C. C., Carvalho, L., De Azevedo, B., and Feigl, B. J. (2009). Bacteria diversity and microbial biomass in the forest, pasture and fallow soils in the Southwestern Amazon basin. R. Bras. Ci. Solo 33, 907-916. doi: 10.1590/s0100-06832009000400015

Chapman, H. D. (1965). "Cation-Exchange Capacity," in Methods of Soil Analysis, ed. C. A. Black (Madison, WI: American Society of Agronomy), 891-901.

Christensen, N. L., and Peet, R. K. (1984). Convergence during secondary forest succession. J. Ecol. 72, 25-36.

Colegrave, N., and Ruxton, G. D. (2018). Using biological insight and pragmatism when thinking about pseudoreplication. Trends Ecol. Evol. 33, 28-35. doi: 10. 1016/j.tree.2017.10.007

Collomb, J.-G., Mikissa, J.-B., Minnemeyer, S., Mundunga, S., Nzao, H. N., Madouma, J., et al. (2000). A First Look at Logging in Gabon. Washington, DC: World Resources Institute.

de Carvalho, T. S., da Conceiçao Jesus, E., Barlow, J., Gardner, T. A., Carvalho Soares, I., Tiedje, J. M., et al. (2016). Land use intensification in the humid tropics increased both alpha and beta diversity of soil bacteria. Ecology 10, 2760-2771. doi: 10.1002/ecy.1513

Dean, W. E. (1974). Determination of carbonate and organic matter in calcareous sediments and sedimentary rocks by loss on ignition: comparison with other methods. J. Sediment. Res. 44, 242-248. 
Dirzo, R., and Raven, P. H. (2003). Global state of biodiversity and loss. Annu. Rev. Environ. Resour. 28, 137-167. doi: 10.1146/annurev.energy.28.050302.105532

Dlott, G., Maul, J. E., Buyer, J., and Yarwood, S. (2015). Microbial rRNA:rRNA gene ratios may be unexpectedly low due to extracellular DNA preservation in soils. J. Microbiol. Methods 115, 112-120. doi: 10.1016/j.mimet.2015.05.027

Dormann, C. F., Schweiger, O., Augenstein, I., Bailey, D., Billeter, R., De Blust, G., et al. (2007). Effects of landscape structure and land-use intensity on similarity of plant and animal communities. Glob. Ecol. Biogeogr. 16, 774-787. doi: 10. $1111 / \mathrm{j} .1466-8238.2007 .00344 . \mathrm{x}$

Edgar, R. C. (2010). Search and clustering orders of magnitude faster than BLAST. Bioinformatics 26, 2460-2461. doi: 10.1093/bioinformatics/btq461

Edgar, R. C. (2013). UPARSE: highly accurate OTU sequences from microbial amplicon reads. Nature 10, 996-1000. doi: 10.1038/NMETH.2604

Ernst, C., Mayaux, P., Verhegghen, A., Bodart, C., Christophe, M., Defourny, P., et al. (2013). National forest cover change in congo basin: deforestation, reforestation, degradation and regeneration for the years 1990, 2000 and 2005. Glob. Change Biol. 19, 1173-1187. doi: 10.1111/gcb.12092

Fadrosh, D. W., Ma, B., Gajer, P., Sengamalay, N., Ott, S., Brotman, R. M., et al. (2014). An Improved dual-indexing approach for multiplexed 16S rRNA gene sequencing on the Illumina MiSeq platform. Microbiome 2, 1-7. doi: 10.1186/ 2049-2618-2-6

Foley, J. A., Defries, R., Asner, G. P., Barford, C., Bonan, G., Carpenter, S. R., et al. (2005). Global consequences of land use. Science 309, 570-574. doi: 10.1126/ science.1111772

Fox, R. L., Olson, R. A., and Rhoades, H. F. (1964). Evaluating the sulfur status of soils by plant and soil tests. Soil Sci. Soc. Am. J. 28, 243-246.

Freedman, Z. B., Romanowicz, K. J., Upchurch, R. A., and Zak, D. R. (2015). Differential responses of total and active soil microbial communities to longterm experimental N deposition. Soil Biol. Biochem. 90, 275-282. doi: 10.1016/ j.soilbio.2015.08.014

Gossner, M. M., Lewinsohn, T. M., Kahl, T., Grassein, F., Boch, S., Prati, D., et al. (2016). Land-use intensification causes multitrophic homogenization of grassland communities. Nature 540, 266-269. doi: 10.1038/nature20575

Gower, J. C. (1971). A general coefficient of similarity and some of its properties. Biometrics 27, 857-871.

Gower, J. C., and Legendre, P. (1986). Metric and euclidean properties of dissimilatory coefficients. J. Classific. 3, 5-48. doi: 10.1007/bf01896809

Griffiths, R. I., Thomson, B. C., James, P., Bell, T., Bailey, M., and Whiteley, A. S. (2011). The bacterial biogeography of British soils. Environ. Microbiol. 13, 1642-1654. doi: 10.1111/j.1462-2920.2011.02480.x

Gumiere, T., Durrer, A., Bohannan, B. J. M., and Dini Andreote, F. (2016). Biogeographical patterns in fungal communities from soils cultivated with sugarcane. J. Biogeogr. 43, 2016-2026. doi: 10.1111/jbi.12775

Hamaoui, G. S., Rodrigues, J. L. M., Bohannan, B. J. M., Tiedje, J. M., and Nüsslein, K. (2016). Land-use change drives abundance and community structure alterations of thaumarchaeal ammonia oxidizers in tropical rainforest soils in Rondonia, Brazil. Appl. Soil Ecol. 107, 48-56. doi: 10.1016/j.apsoil.2016.05.012

Hermans, S. M., Buckley, H. L., Case, B. S., Curran-Cournane, F., Taylor, M., and Lear, G. (2017). Bacteria as emerging indicators of soil condition. Edited by Frank E Loeffler. Appl. Environ. Microbiol. 83, e2826-16. doi: 10.1128/AEM. 02826-16

Hooper, D. U., Adair, E. C., Cardinale, B. J., Byrnes, J. E. K., Hungate, B. A., Matulich, K. L., et al. (2012). A global synthesis reveals biodiversity loss as a major driver of ecosystem change. Nature 486, 105-108. doi: 10.1038/ nature11118

Houghton, R. A. (1994). The worldwide extent of land-use change. Bioscience 44, 305-313. doi: $10.2307 / 1312380$

Hurlbert, S. H. (1984). Pseudoreplication and the design of ecological field experiments. Ecol. Monogr. 54, 187-211. doi: 10.2307/1942661

Jones, A., Breuning-Madsen, H., Brossard, M., Dampha, A., Deckers, J., Dewitte, O., et al. (2013). Soil Atlas of Africa. Luxembourg: The European Commission, 76. doi: $10.2788 / 52319$

Jones, S. E., and Lennon, J. T. (2010). Dormancy contributes to the maintenance of microbial diversity. Proc. Natl. Acad. Sci. U.S.A. 107, 5881-5886. doi: 10.1073/ pnas. 0912765107

Jost, L., Chao, A., and Chazdon, R. L. (2011). "Compositional Similarity and Beta Diversity," in Biological Diversity: Frontiers in Measurement and Assessment, eds A. E. Magurran, and B. McGill, (Oxford: Oxford University Press), 66-84.
Jurasinski, G., and Retzer, V. (2012). Simba: A Collection of Functions for Similarity Analysis of Vegetation Data. Available at: https://cran.r-project.org/package= simba (accessed July, 2014).

Kamke, J., Taylor, M. W., and Schmitt, S. (2010). Activity profiles for marine sponge-associated bacteria obtained by $16 \mathrm{~S}$ rRNA vs $16 \mathrm{~S}$ rRNA gene comparisons. ISME J. 4, 498-508. doi: 10.1038/ismej.2009.143

Kamprath, E. J., and Watson, M. E. (1980). "Conventional soil and tissue tests for assessing the phosphorus status of soils," in The Role of Phosphorus in Agriculture, eds F. E. Khasawneh, E. C. Sample, and E. J. Kamprath (Madison, WI: American Society of Agronomy), 433-469.

Kozich, J. J., Westcott, S. L., Baxter, N. T., Highlander, S. K., and Schloss, P. D. (2013). Development of a dual-index sequencing strategy and curation pipeline for analyzing amplicon sequence data on the MiSeq illumina sequencing platform. Appl. Environ. Microbiol. 79, 5112-5120. doi: 10.1128/AEM. 01043-13

Kuczynski, J., Liu, Z., Lozupone, C., Mcdonald, D., Fierer, N., Knight, R., et al. (2010). Microbial community resemblance methods differ in their ability to detect biologically relevant patterns. Nat. Methods 7, 813-821. doi: 10.1038/ nmeth.1499

Laurance, W. F. (2015). Emerging threats to tropical forests. Annals of the Missouri Botanical Garden 100, 159-169. doi: 10.3417/2011087

Laurance, W. F., Alonso, A., Lee, M., and Campbell, P. (2006). Challenges for forest conservation in Gabon, Central Africa. Futures 38, 454-470. doi: 10.1016/ j.futures.2005.07.012

Laurance, W. F., Sayer, J., and Cassman, K. G. (2014). Agricultural expansion and its impacts on tropical nature. Trends Ecol. Evol. 29, 107-116. doi: 10.1016/j. tree.2013.12.001

Lee, M. E., Alonso, A., Dallmeier, F., Campbell, P., and Pauwels, O. S. G. (2006). The gamba complex of protected areas: an illustration of gabon's biodiversity. Bull. Biol. Soc. Washington 12, 229-242.

Lee-Cruz, L., Edwards, D. P., Tripathi, B. M., and Adams, J. M. (2013). Impact of logging and forest conversion to oil palm plantations on soil bacterial communities in Borneo. Appl. Environ. Microbiol. 79, 7290-7297. doi: 10.1128/ AEM.02541-13

Legendre, P. (1993). Spatial autocorrelation: trouble or new paradigm? Ecology 74 , 1659-1673. doi: $10.2307 / 1939924$

Legendre, P., and Legendre, L. (1998). Ecological resemblance. Num. Ecol. 24, 247-302. doi: 10.1016/s0167-8892(98)80059-6

Lennon, J. T., and Jones, S. E. (2011). Microbial seed banks: the ecological and evolutionary implications of dormancy. Nat. Rev. Microbiol. 9, 119-130. doi: 10.1038/nrmicro2504

Lennon, J. T., Placella, S. A., and Muscarella, M. E. (2017). Relic DNA contributes minimally to estimates of microbial diversity. bioRxiv 0-28. doi: 10.1101/ 131284

Lepš, J. (1991). Convergence or divergence: what should we expect from vegetation succession? Oikos 62, 261-264.

Louca, S., Parfrey, L. W., and Doebli, M. (2016). Decoupling function and taxonomy in the global ocean microbiome. Science 353, 1272-1277. doi: 10. $1126 /$ science.aaf 4507

Love, M. I., Huber, W., and Anders, S. (2014). Moderated estimation of fold change and dispersion for RNA-Seq data with DESeq2. Genome Biol. 15:550. doi: 10.1186/s13059-014-0550-8

Maechler, M., Rousseeuw, P., Struyf, A., Hubert, M., and Hornik, K. (2016). Cluster: Cluster Analysis Basics and Extensions. R package version 2.0.5.

Mcguire, K. L., D’Angelo, H., Brearley, F. Q., Gedallovich, S. M., Babar, N., Yang, N., et al. (2015). Responses of soil fungi to logging and oil palm agriculture in Southeast Asian tropical forests. Microb. Ecol. 69, 733-747. doi: 10.1007/ s00248-014-0468-4

McKinney, M. L., and Lockwood, J. L. (1999). Biotic homogenization: a few winners replacing many losers in the next mass extinction. Trends Ecol. Evol. 14, 450-453. doi: 10.1016/s0169-5347(99)01679-1

Meyer, K. M., Klein, A. M., Rodrigues, J. L. M., Nüsslein, K., Tringe, S., Mirza, B., et al. (2017). Conversion of Amazon rainforest to agriculture alters community traits of methane-cycling organisms. Mol. Ecol. 26, 1547-1556. doi: 10.1111/ mec. 14011

Meyer, K. M., Petersen, I. A. B., Tobi, E., Korte, L., and Bohannan, B. (2018). Use of RNA and DNA to identify mechanisms of microbial community homogenization. bioRxiv 
Mirza, B. S., Potisap, C., Nüsslein, K., Bohannan, B. J. M., and Rodrigues, J. L. M. (2014). Response of free-living nitrogen-fixing microorganisms to land use change in the Amazon rainforest. Appl. Environ. Microbiol. 80, 281-288. doi: 10.1128/AEM.02362-13

Mueller, R. C., Paula, F. S., Mirza, B. S., Rodrigues, J. L., Nüsslein, K., and Bohannan, B. J. (2014). Links between plant and fungal communities across a deforestation chronosequence in the Amazon rainforest. ISME J. 8, 1548-1550. doi: 10.1038/ismej.2013.253

Mueller, R. C., Rodrigues, J. L., Nüsslein, K., and Bohannan, B. J. (2016). Land use change in the Amazon rainforest favors generalist fungi. Funct. Ecol. 30, 1845-1853. doi: 10.1111/1365-2435.12651

Naughton-Treves, L., and Weber, W. (2001). "Human Dimensions of the African Rain Forest," in African Rain Forest Ecology and Conservation, eds W. Weber, L. J. T. White, A. Vedder, and L. Naughton-Treves (New Haven, CT: Yale University Press), 30-49.

Navarrete, A. A., Tsai, S. M., Mendes, L. W., Faust, K., de Hollander, M., Cassman, N. A., et al. (2015a). Soil microbiome responses to the short-term effects of Amazonian deforestation. Mol. Ecol. 24, 2433-2448. doi: 10.1111/mec.13172

Navarrete, A. A., Venturini, A. M., Meyer, K. M., Klein, A. M., Tiedje, J. M., Bohannan, B. J., et al. (2015b). Differential response of acidobacteria subgroups to forest-to-pasture conversion and their biogeographic patterns in the Western Brazilian Amazon. Front. Microbiol. 6:1443. doi: 10.3389/fmicb.2015.01443

Nekola, J. C., and White, P. S. (1999). The distance decay of similarity in biogeography and ecology. J. Biogeogr. 26, 867-878. doi: 10.1046/j.1365-2699. 1999.00305.x

Oksanen, J., Blanchet, F. G., Roeland, K., Legendre, P., Minchin, P., O’Hara, R. B., et al. (2015). Vegan: Community Ecology Package. Available at: http://cran.rproject.org (accessed July, 2014).

Oksanen, L. (2001). Logic of experiments in ecology: is pseudoreplication a pseudoissue? Oikos 94, 27-38. doi: 10.1034/j.1600-0706.2001.11311.x

Olden, J. D., and Poff, N. L. (2003). Toward a mechanistic understanding and prediction of biotic homogenization. Am. Nat. 162, 442-460. doi: 10.1086/ 378212

Olden, J. D., and Rooney, T. P. (2006). On defining and quantifying biotic homogenization. Glob. Ecol. Biogeogr. 15, 113-120. doi: 10.1111/j.1466-822x. 2006.00214.x

Olsen, S. R. (1954). Estimation of Available Phosphorus in Soils by Extraction with Sodium Bicarbonate. Washington, DC: United States Department of Agriculture Circular.

Papp, K., Hungate, B. A., and Schwartz, E. (2018a). Microbial rRNA synthesis and growth compared through quantitative stable isotope probing with $\mathrm{H} 218 \mathrm{O}$. Appl. Environ. Microbiol. 84, 1-11. doi: 10.1128/AEM.02441-17

Papp, K., Mau, R. L., Hayer, M., Koch, B. J., Hungate, B. A., and Schwartz, E. (2018b). Quantitative stable isotope probing with $\mathrm{H} 218 \mathrm{O}$ reveals that most bacterial taxa in soil synthesize new ribosomal RNA. ISME J. 12, 3043-3045. doi: 10.1038/s41396-018-0233-7

Paula, F. S., Rodrigues, J. L. M., Zhou, J., Wu, L., Mueller, R. C., Mirza, B. S., et al. (2014). Land use change alters functional gene diversity, composition and abundance in Amazon forest soil microbial communities. Mol. Ecol. 23, 2988-2999. doi: 10.1111/mec.12786

R Core Team. (2018). R: A Language and Environment for Statistical Computing. Vienna: R Foundation for statistical computing.

Ranjard, L., Dequiedt, S., Chemidlin Prévost-Bouré, N., Thioulouse, J., Saby, N. P., Lelievre, M., et al. (2013). Turnover of soil bacterial diversity driven by wide-scale environmental heterogeneity. Nat. Commun. 4:1434. doi: 10.1038/ ncomms 2431

Rodrigues, J. L. M., Pellizari, V. H., Mueller, R., Baek, K., Jesus, E. D. C., Paula, F. S., et al. (2013). Conversion of the Amazon rainforest to agriculture results in biotic homogenization of soil bacterial communities. Proc. Natl. Acad. Sci. U.S.A. 110, 988-993. doi: 10.1073/pnas.1220608110
Romanowicz, K. J., Freedman, Z. B., Upchurch, R. A., Argiroff, W. A., and Zak, D. R. (2016). Active microorganisms in forest soils differ from the total community yet are shaped by the same environmental factors: the influence of pH and soil moisture. FEMS Microbiol. Ecol. 92, 1-9. doi: 10.1093/femsec/ fiw149

Sannier, C., McRoberts, R. E., Fichet, L.-V., and Makaga, E. M. K. (2014). Using the regression estimator with landsat data to estimate proportion forest cover and net proportion deforestation in gabon. Remote Sens. Environ. 151, 138-148. doi: 10.1016/j.rse.2013.09.015

Schank, J. C., and Koehnle, T. J. (2009). Pseudoreplication is a pseudoproblem. J. Comp. Psychol. 123, 421-433. doi: 10.1037/a0013579

Simard, R. R. (1993). “Ammonium Acetate-Extractable Elements," in Soil Sampling and Methods of Analysis, ed. M. R. Carter (Oxford: Lewis Publishers), 39-42.

Steven, B., Hesse, C., Soghigian, J., and Gallegos-Graves, L. V. (2017). Simulated rRNA / DNA ratios show potential to misclassify active populations as dormant. Appl. Environ. Microbiol. 83, e696-17. doi: 10.1128/AEM.006 96-17

Sul, W. J., Asuming-brempong, S., Wang, Q., Tourlousse, D. M., Penton, C. R., Deng, Y., et al. (2013). Tropical agricultural land management influences on soil microbial communities through its effect on soil organic carbon. Soil Biol. Biochem. 65, 33-38. doi: 10.1016/j.soilbio.2013.05.007

Tripathi, B. M., Edwards, D. P., Mendes, L. W., Kim, M., Dong, K., Kim, H., et al. (2016). The impact of tropical forest logging and oil palm agriculture on the soil microbiome. Mol. Ecol. 25, 2244-2257. doi: 10.1111/mec.13620

Vellend, M., Verheyen, K., Flinn, K. M., Jacquemyn, H., Kolb, A., Calster, H. V. A. N., et al. (2007). Homogenization of forest plant communities and weakening of species - environment relationships via agricultural land use. J. Ecol. 95, 565-573. doi: 10.1111/j.1365-2745.2007.01233.x

White, L. J. T. (2001). "The African Rain Forest: Climate and Vegetation," in African Rain Forest Ecology and Conservation, eds W. Weber, L. J. T. White, L. Naughton-Treves, and A. Vedder (New Haven, CT: Yale University Press), 3-29.

Wickham, H. (2009). ggplot2: Elegant Graphics for Data Analysis. Berlin: Springer Science \& Business Media.

Wilkie, D. S., and Laporte, N. (2001). "Forest Area and Deforestation in Central Africa: Current Knowledge and Future Directions," in African Rain Forest Ecology and Conservation, eds W. Weber, L. J. T. White, L. Naughton-Treves, and A. Vedder (New Haven, CT: Yale University Press), 119-139.

Wood, S. A., Bradford, M. A., Gilbert, J. A., Mcguire, K. L., Palm, C. A., Tully, K. L., et al. (2015). Agricultural intensification and the functional capacity of soil microbes on smallholder african farms. J. Appl. Ecol. 52, 744-752. doi: 10.1111/1365-2664.12416

Wood, S. A., Gilbert, J. A., Leff, J. W., Fierer, N., Angelo, H. D., Bateman, C., et al. (2017). Consequences of tropical forest conversion to oil palm on soil bacterial community and network structure. Soil Biol. Biochem. 112, 258-268. doi: 10.1016/j.soilbio.2017.05.019

Zhang, Y., Zhao, Z., Dai, M., Jiao, N., and Herndl, G. J. (2014). Drivers shaping the diversity and biogeography of total and active bacterial communities in the South China sea. Mol. Ecol. 23, 2260-2274. doi: 10.1111/mec.12739

Conflict of Interest Statement: The authors declare that the research was conducted in the absence of any commercial or financial relationships that could be construed as a potential conflict of interest.

Copyright (C) 2019 Meyer, Petersen, Tobi, Korte and Bohannan. This is an open-access article distributed under the terms of the Creative Commons Attribution License (CC BY). The use, distribution or reproduction in other forums is permitted, provided the original author(s) and the copyright owner(s) are credited and that the original publication in this journal is cited, in accordance with accepted academic practice. No use, distribution or reproduction is permitted which does not comply with these terms. 